\title{
Analysis of the surgical treatment of the patients operated on by using laparoscopic and classic splenectomy due to benign disorders of the spleen
}

\author{
Vladimir Milosavljevic ${ }^{1}$, Boris Tadic ${ }^{1}$, Nikola Grubor ${ }^{1}$, Dragan Eric ${ }^{1}$, Milorad Reljic ${ }^{1}$, Slavko Matic ${ }^{2}$ \\ 1 Department of Hepatobiliary and Pancreatic Surgery, Clinic of Digestive Surgery, Clinical Centre of Serbia, Belgrade, Serbia \\ ${ }^{2}$ Department of Surgery, Belgrade University School of Medicine, Belgrade, Serbia
}

\begin{abstract}
Objective: Laparoscopic splenectomy became the standard surgical procedure in the 1990s. The goal of this study was to analyze the outcome of the patients who underwent laparoscopic splenectomy for the benign hematologic diseases of the spleen and compare its results with open splenectomy. Material and Methods: The study was conducted as a retrospective cohort study analyzing and comparing the data obtained from 196 patients' case records in the Clinic for Digestive Surgery, Clinical Center of Serbia, for the benign disorders of the spleen, divided into two groups: patients operated with laparoscopic technique and patients in whom classic splenectomy was performed. The analyzed parameters were divided into three groups as preoperative, intraoperative and postoperative.

Results: In the laparoscopic splenectomy group, less intraoperative blood loss, lower incidental intraoperative complications and a shorter duration of surgery were recorded. The incidence of postoperative complications and reoperations was higher in the group of classically operated patients. Postoperative recovery, expressed by the duration of postoperative abdominal drainage, recovery of intestinal peristalsis and length of postoperative hospitalization, was significantly shorter in the laparoscopic group.

Conclusion: Laparoscopic splenectomy is an effective and safe surgical procedure in the treatment of many benign diseases of the spleen. Improvement of the laparoscopic technique of surgical teams and technical improvement of the laparoscopic equipment can lead to even wider application of laparoscopic splenectomy as standard operative procedure, and thus to safer and better quality treatment of patients with wider spectrum diseases of the spleen.
\end{abstract}

Keywords: Laparoscopy, spleen, laparoscopic splenectomy, benign disorders of the spleen

Cite this article as: Milosavljevic V, Tadic B, Grubor N, Eric $\mathrm{D}$, Reljic M, Matic S. Analysis of the surgical treatment of the patients operated on by using laparoscopic and classic splenectomy due to benign disorders of the spleen. Turk J Surg 2019; 35 (2): 111-116

\section{Corresponding Author}

Boris Tadic

E-mail: tadicboris@yahoo.com

Received: 09.10.2018

Accepted: 05.11 .2018

Available Online Date: 13.06 .2019

o Copyright 2019 by Turkish Surgical Society Available online at www.turkjsurg.com

DOI: $10.5578 /$ turkjsurg. 4324

\section{INTRODUCTION}

The first laparoscopic splenectomy in the world was done by Delaitre and Maignien in 1991 (1). For the past decade, laparoscopic splenectomy has become widely accepted and applicable in the treatment of many diseases of the spleen. The most common benign hematologic diseases of the spleen in which splenectomy is indicated are immune thrombocytopenic purpura (ITP), thrombotic thrombocytopenic purpura, hereditary spherocytosis, autoimmune hemolytic anemia, benign tumors, and splenic cysts (2).

Indications for laparoscopic splenectomy are the same as for open (classic) splenectomy, except in cases of trauma, where the role of laparoscopy is still the subject of consideration.

The goal of this study was to analyze the outcome of the patients undergoing laparoscopic splenectomy due to benign hematologic diseases of the spleen and compare the surgical treatment results with an open splenectomy and the present the importance of laparoscopic approach in the treatment of benign disorders of the spleen.

\section{MATERIAL and METHODS}

The study was conducted as a retrospective cohort study. The data obtained from the history of the disease was analyzed and compared, with the aim of getting 
insight into certain parameters. The study covered a total of 196 patients operated on due to benign diseases of the spleen at the Clinic for Digestive Surgery - the First Surgical Clinic of the Clinical Center of Serbia. Informed consent was not received due to the retrospective nature of the study. Ethics committee approval was received for this study from the local ethics committee of the Clinical Centre of Serbia.

Patients were divided into two groups. The first group consisted of 93 patients who were operated on by using the laparoscopic technique (LS) in the period from 2007 to 2017 and the second group consisted of 103 patients operated on by using the classic approach (CS) in the period from 2001 to 2017.

The choice of surgical technique or approach was based on certain characteristics of the patient: type of the disease (e.g. in the case of a tumor of the spleen, the classic approach had the advantage, so that the preparation for the pathohistological analysis would be comprehensive, the size of the spleen also had an important role in the choice of the approach, larger spleens were operated on using the classic approach, as well as patients with comorbidities which presented a contraindication for laparoscopic surgery).

Laparoscopic splenectomy began its application at the First Surgical Clinic in 2007, since then and until 2017, patients from this group have been monitored. A group of patients operated on using the classic approach has been monitored since 2001 in order to have similar groups for comparison, because since 2007 there has been a significantly greater number of laparoscopic surgeries; however, after the introduction of a laparoscopic procedure and due to expressed contraindications with this approach or due to technical reasons, classic splenectomy was performed.

For patients operated on due to benign hematological diseases, diagnosis and primary drug therapy were performed by a hematologist. Platelets were analyzed daily in the preoperative period, as well as from the first postoperative day until the release of the patient, in order to have an insight into the therapeutic effects of the patients operated on.

Patients were treated with low molecular weight heparin (Fraxiparine, Aspen Notre Dame de Bondeville, France), with the addition of anticoagulation therapy in cases of a platelet count increase at $>500 \times 10^{9} / \mathrm{L}$. Corticosteroid therapy was gradually reduced until complete suspension.

For patients who were operated on due to benign, nonhematological diseases of the spleen (benign tumors and cysts), the diagnosis was made by means of ultrasound examination, computerized tomography, and magnetic resonance imaging of the abdomen.

Parameters that were compared and monitored in both groups of the patients were: 1. Preoperative, which included: gender, age, body mass index, diagnosis of the disease, and size of the spleen (measured within the preoperative diagnosis); however, for hematological patients, preoperative number of platelets and length of hematologic treatment were also recorded. 2. Intraoperative, which included: intraoperative blood loss (amount of blood from the operative section aspirated through the suction system and then measured with the help of burettes), duration of the operation (measured in minutes), intraoperative complications (bleeding, injuries of other organs etc.), and for LS groups, conversion into open procedure and detection of accessory spleen. 3. Postoperative, which included: the time period in which the drain and the nasogastric tube were taken out (measured in days). Reintervention, most commonly due to infection, surgical wound disruption, intra-abdominal collection, abscess, pancreatic fistula etc., the length of postoperative hospitalization, and for benign hematological diseases, the postoperative number of platelets in order to gain insight into the therapeutic effect of the surgical treatment.

In all postoperative patients, prophylactic antibiotic therapy (Amoxycillin, Hemofarm Stada, Serbia) was administered during the postoperative course according to all current guides $(3,4)$. Furthermore, all patients were postoperatively vaccinated according to current vaccination protocols (5). Dindo-Clavien scale was used to evaluate postoperative complications (6).

The study did not include patients with malignant hematological disorders and patients with associated cardiovascular comorbidities, as well as patients in whom the surgical procedure was contraindicated.

Statistical Package for the Social Sciences version 21.0 (IBM Corp.; Armonk, NY, USA) program was used for data analysis. If they met the criteria of normal distribution, the results were presented in the form of an arithmetic mean and standard deviation. Otherwise, they were represented by the median and the range of values. Categorical data are presented with absolute and percentage values. T-test was applied to compare continuous variables subjected to normal distribution, otherwise the Mann-Whitney test was used. The X2 test was used to analyze categorical type data. All statistical methods were considered significant if $p(p)$ value $\leq 0.05$.

\section{RESULTS}

Out of a total of 196 patients who were involved in the study, 93 of them were in the laparoscopic group, while the classic group included 103 subjects.

The groups tested did not differ much when it came to gender distribution, genders were equally represented $(p=0.461)$, the LS group had 38 (40.4\%) male and 56 (59.6\%) female patients, while the classic group had 47 (45.6\%) male and 56 (54.4\%) female patients. 
Average age of these two groups was the same ( $p=0.096)$. Patients in the LS group were on average $38.24 \pm 13.6$ years old, while CS group patients were $41.68 \pm 15.02$ years old. Average nutrition value in the LS group was $25.62 \pm 2.73 \mathrm{~kg} / \mathrm{m}^{2}$, while the CS group patients amounted to $26.43 \pm 2.43 \mathrm{~kg} / \mathrm{m}^{2}$.

Different types of disease (AlHA, benign tumors, cystic, ITP and spherocytosis) were equally represented in both groups ( $p=$ 0.184). The representation of various diseases in the groups tested is shown in Table 1.

The difference in spleen size was as follows: LS group (13.24 \pm $1.82 \mathrm{~cm})$ and $\mathrm{CS}$ group $(14.34 \pm 3.21 \mathrm{~cm})$. Larger spleen was the case in the classic group.

There was no significant difference in preoperative platelet counts between the groups tested $(p=0.164)$. In the LS group, the value was $71.78 \pm 14.52$, while in the CS group, it was $68.29 \pm$ 14.81. Additionally, the length of hematological treatment of these two groups was not different as well $(p=0.474)$. The laparoscopic group was treated with preoperative medication for 23 months (10-120), and those that in the classic group for 30 months (10-120).

The presence of accessory spleens in the LS group was 19 (20.2\%) and 11 (10.7\%) in the CS group. A percentage difference in the presence of accessory spleen was noticed.

Intraoperative bleeding was significantly more extensive during classic splenectomy, rather than during laparoscopic splenectomy $(p<0.001)$. In the LS group, it resulted in $32 \mathrm{~mL}(5-225)$ and $56 \mathrm{~mL}$ (10-310) in the CS group.

Intraoperative complications of the patients were noticed in 4 (4.3\%) patients of the LS group, and in 7 (7.4\%) patients of the classic group. The need for reintervention was significantly more frequent in the classic group (7.8\%), while the laparoscopic group had no need for reintervention. There was a single fatal outcome in the laparoscopic group, while the classic group had two fatal outcomes. There were no statistically significant differences in the frequency of fatal outcomes between these two treatments.

The laparoscopic technique surgery was significantly shorter when compared to the classic surgery, $83.46 \pm 14.40$ compared to $91.80 \pm 15.32$ minutes, respectively. A statistically significant difference in the duration of these two interventions was proven in favor of the laparoscopic surgery $(p<0.001)$.

Abdominal drain and nasogastric tube were placed significantly longer during classic surgery than during laparoscopic surgery $(p<0.001$ and $p<0.001)$. Average duration of abdominal drain retention after laparoscopic surgery was 2 days, a minimum of 1 and a maximum of 3 , while the average duration in the classic surgery group was 3 days, with a minimum of 1 and a maximum of 15 days. The nasogastric tube was retained on average for 2 days (1-3) in the LS group and 3 (2-7) days in the CS group.

Average postoperative hospitalization for the LS group lasted for 4 days, with a minimum of 2 and a maximum of 12, while for the CS group it was significantly longer, on average 9 days, with a minimum of 7 days and a maximum of 22 days.

Different incidence and severity of postoperative complications according to Dindo-Clavien Classification (DC) were shown, with I, then II and class III that were significantly represented in the classic group ( $p=0.006 ; p=0.002 ; p=0.005)$.

In the LS group, there were 9 subjects of gradus I according to Dindo-Clavien Classification. These patients required additional, postoperative drug therapy in the form of antibiotics, antiemetics and antipyretics. Six patients belonged to gradus II according to DC classification and required additional antibiotic therapy. One patient had percutaneous drainage of the collection from a loge that was surgically removed from the spleen (grade III). A single myocardial infarction (grade IV) was recorded in one patient, and finally one deadly outcome was noted due to fulminant sepsis, after a series of non-surgical complications (gradus V).

In the CS group, these numbers were significantly higher. 25 patients were gradus I and 23 cases were gradus II. Eleven patients were in gradus III, followed by 5 patients in gradus IV. Two of the patients died after a series of complications (grade V). The representation of DC classification in the groups tested is shown in Table 2.

Table 1. Representation of various diseases in the group

\begin{tabular}{|c|c|c|c|}
\hline \multirow[b]{2}{*}{ Diseases of the spleen } & \multicolumn{2}{|c|}{ Group } & \multirow[b]{2}{*}{$p$} \\
\hline & Laparoscopic splenectomy n (\%) & Classic slenectomy $\mathrm{n}(\%)$ & \\
\hline AlHA & $2(2.1)$ & $4(3.9)$ & \multirow{5}{*}{0.1841} \\
\hline Benign tumors & $5(5.3)$ & $15(14.6)$ & \\
\hline Cysts & $19(20.2)$ & $14(13.6)$ & \\
\hline ITP & $58(61.7)$ & $58(56.3)$ & \\
\hline Spherocytosis & $10(10.6)$ & $12(11.7)$ & \\
\hline
\end{tabular}


Table 2. Representation of DC classification in the groups

\begin{tabular}{|l|c|c|c|}
\hline & \multicolumn{2}{|c|}{ Group } & \\
\hline (DC) gradus & Laparoscopic Splenectomy n (\%) & Classic splenectomy $\mathbf{n}(\%)$ & $\mathbf{p}$ \\
\hline I & $9(9.6)$ & $25(24.3)$ & 0.006 \\
\hline II & $6(6.4)$ & $23(22.3)$ & 0.002 \\
\hline III & $1(1.1)$ & $11(10.7)$ & 0.005 \\
\hline IV & $1(1.1)$ & $5(4.9)$ & 0.122 \\
\hline V & $1(1.1)$ & $2(1.9)$ & 0.615 \\
\hline DC: Dindo-Clavien classification. & & & \\
\hline
\end{tabular}

\section{DISCUSSION}

The first laparoscopic splenectomy was done 27 years ago in Paris by Delaitrea and Maignien. Shortly after, the initial objectives of laparoscopic splenectomy were defined, and they meant the following: that the results were identical to the classic splenectomy in terms of efficiency and safety, followed by reduced abdominal wall trauma, easier postoperative period and shorter hospitalization (1).

A special advantage is given to laparoscopic splenectomy when it comes to hematological disorders. These patients generally take corticosteroid therapy, which can have an impact on the development of infections and dehiscence of the surgical wound, and taking into account all the benefits achieved by the laparoscopic technique, laparoscopic splenectomy is the gold standard when it comes to these diseases $(7,8)$.

The age of the patients who were laparoscopically operated on was $38.24 \pm 13.6$ years, while those that were subjected to classic surgery were $41.68 \pm 15.02$ years old.

The most common indication for splenectomy among benign hematological diseases is immune thrombocytopenic purpura (ITP). The frequency of this disease is ranging, according to some authors, from $60-80 \%$ (2). According to the results of our study in the LS group of patients, $61.7 \%$ of them were operated on due to ITP, while that only happened to $56.3 \%$ of those in the CS group. According to percentage representation, our data does not deviate from the data in the literature.

Average treatment time by the hematologist in the LS group was on average 23 (10-120) months while this number amounted to 30 (10-120) months in the classic group. Preoperative platelet counts in the LS group amounted to $71.78 \pm 14.52 \times 10^{9} / \mathrm{L}$ while the same value went as high as $68.29 \pm 14.81 \times 10^{9} / \mathrm{L}$ in the classic group, meaning there was no significant statistical difference between the groups regarding the duration of the preoperative treatment, as well as the platelet count preoperatively.

Accessory spleens are found in about $10-15 \%$ of the adults. Usually, they are between 1 and $2 \mathrm{~cm}$. An accessory spleen in our study was present in 19 (20.2\%) patients in the laparoscopic group of patients and in 11 (10.7\%) patients in the classic group.
According to our study, intraoperative blood loss was $32 \mathrm{~mL}$ (5$225)$ in the LS group of patients, while it went as high as $56 \mathrm{~mL}$ (10-310) in the classic group. In a study by Rozario et al., the average intraoperative bleeding in the LS group of patients was 40 ml (0-150) (2). Italian authors Nobili et al. have published a study in which intraoperative bleeding during laparoscopic splenectomy was $60 \mathrm{~mL}$ (30-500) (9).

In our study, in patients who underwent laparoscopic splenectomy, a conversion was performed into an open procedure in four cases. In all four cases, the conversion was due to intraoperative bleeding. The bleeding was due to instrumental rupture of the spleen in one patient, due to poorly placed endovascular stapler in two patients, due to arterial injury to the lower half of the spleen in one patient.

In the US National Register, between 2005 and 2010, 37006 splenectomies were recorded, showing a worrying percentage of conversions of 22.5-33.99\%, with very few patients being treated with laparoscopic technique at around 13.3\% (10). Some authors point to a small conversion rate into an open procedure with a percentage of around $0-4 \%$ depending on the type of intraoperative complication when it comes to increased intraoperative bleeding and when splenomegaly is present $(9,11)$. In our study, the percentage of intraoperative complications in the LS group amounted to 4.3\%, and those were the cases were intraoperative bleeding and conversion took place, while in the classic group, it was 7.4\%, where besides intraoperative bleeding, there were also injuries of the tail of the pancreas and damages to the stomach wall.

Average duration of the surgery according to the data from our study in the LS group was $83.46 \pm 14.40$ minutes, while the average duration of surgery in the CS group was $91.80 \pm 15.32$ minutes.

According to many studies, the percentage of reintervention ranges between $0-6.7 \%$ (11-13). In our study, there were no reinterventions in the laparoscopic group, whereas there were eight in the classic group. Reinterventions in the CS group of patients were due to bleeding, fistula, intra-abdominal collections/abscesses and surgical wound disruptions. 
Literature data indicates a significantly lower percentage of postoperative complications in patients operated on laparoscopically. Winslow et al. have performed a meta-analysis of 51 series out of a total of 2940 patients, out of whom 2119 were laparoscopically operated on and 821 underwent the classic surgery, and demonstrated a statistically lower percentage of complications in the group of patients under laparoscopic treatment, which was $15.5 \%$ compared to $26.6 \%$ for the classic treatment (14).

Postoperative hospitalization, according to the results of the majority of authors, ranges from 1 to 25 days and is mainly dependent on the performance or simultaneous additional surgeries, most often laparoscopic cholecystectomies, then the age of patients, where a longer stay in the hospital is related to their older age, as well as postoperative complications $(9,12)$.

Average postoperative hospitalization according to the results of our study was 4 (2-12) days for the LS group, whereas for the CS group, the average postoperative hospitalization amounted to 9 (7-22) days.

Some authors advocate that after each splenectomy, it should be mandatory to place the drain in the left subphrenic space, sometimes even two drains in cases of the classic group, although there are authors who complain that the drain should not be placed routinely, but only in cases of pancreatic injury (1517). In addition to the above mentioned postoperative parameters in our study, we also dealt with a time period in which, after splenectomy, the drain and nasogastric suction were removed. In our study, after each splenectomy, we placed the drains, and the average time that elapsed until the elimination of the drain and after the surgery in the LS group was 2 days (1-3 days), while in the CS group this time was on average 3 days (1-15 days). As for the average time that elapsed until the removal of the nasogastric tube, in the LS group, it was 2 days (1-3 days), while in the CS group, it was 3 days (2-7) days.

Gonzales et al. have published 89\% good response after laparoscopic and open splenectomy in their study (18). Zheng et al. have published a ten-year long experience in laparoscopic splenectomy in treating ITP in which they have reported the results of the success of the treatment, with percentages ranging between $80.3-89 \%$ retrospectively (19).

In our study, the best therapeutic response was most represented, and the worst one was least represented. In one patient within the LS group and two patients in the CS group, therapeutic outcomes were unknown due to fatal outcomes. In the laparoscopic group, complete therapeutic response was the case in $83.8 \%$ of patients, while the same value went as high as $80 \%$ in the classic group.

\section{CONCLUSION}

The official position of most European and World guides on surgical practice today is that LS is indicated for most benign and malignant diseases of the spleen, where an indication for surgical treatment exists, regardless of the age or body weight of the patient. Our study has confirmed the fact that laparoscopic splenectomy is an effective and safe surgical procedure in the treatment of many benign and malignant diseases of the spleen. The results speak strongly in favor of better detection of accessory spleens in the group of patients in whom laparoscopic splenectomy has been performed. Speaking of proven advantage of the laparoscopic approach in relation to preoperative diagnostics, we can conclude that laparoscopic splenectomy, both in terms of diagnostics and therapeutic effect, has advantages over classical surgery. Further sophistication of laparoscopic surgical techniques technical improvements of laparoscopic equipment can lead to even wider application of LS as a standard surgical procedure, and thus to a safer and better treatment of patients with a wide spectrum of spleen diseases.

Ethics Committee Approval: Ethics committee approval was received for this study from the local ethics committee of the Clinical Centre of Serbia.

Informed Consent: Written informed consent was obtained from patients who participated in this study.

Peer-review: Externally peer-reviewed.

Author Contributions: Concept - V.M., B.T., N.G.; Design - V.M., B.T.; Supervision - S.M., D.E.; Resource - N.G., V.M.; Materials - B.T., M.R., N.G.; Data Collection and/or Processing - V.M., B.T., M.R.; Analysis and/or Interpretation - V.M., B.T., S.M.; Literature Search - M.R., D.E., N.G.; Writing Manuscript - V.M., B.T.; Critical Reviews - S.M., B.T., N.G.

Conflict of Interest: No conflict of interest was declared by the authors.

Financial Disclosure: The authors declared that this study has received no financial support.

\section{REFERENCES}

1. Delaitre B, Maignien B, Icard P. Laparoscopic splenectomy. Br J Surg 1992; 79: 1334. [CrossRef]

2. Vecchio R, Marchese S, Intagliata E, Swehli E, Ferla F, Cacciola E. Longterm results after splenectomy in adult idiopathic thrombocytopenic purpura: comparison between open and laparoscopic procedures. $J$ Laparoendosc Adv Surg Tech A 2013; 23: 192-8. [CrossRef]

3. Di Sabatino A, Carsetti $R$, Corazza GR. Post-splenectomy and hyposplenic states. Lancet 2011; 378: 86-97. [CrossRef]

4. Davies JM, Lewis MP, Wimperis J, Rafi I, Ladhani S, Bolton-Maggs PH, et al. Review of guidelines for the prevention and treatment of infection in patients with an absent or dysfunctional spleen: prepared on behalf of the British Committee for Standards in Haematology by a working party of the Haemato-Oncology task force. Br J Haematol 2011; 155: 308-17. [CrossRef] 
5. Buzele R, Barbier L, Sauvanet A, Fantin B. Medical complications following splenectomy. J Visc Surg 2016; 153: 277-86. [CrossRef]

6. Dindo D, Demartines N, Clavien PA. Classification of surgical complications: a new proposal with evaluation in a cohort of 6336 patients and results of a survey. Ann Surg 2004; 240: 205-13. [CrossRef]

7. Glasgow RE, Mulvihill SJ. Laparoscopic splenectomy. World J Surg 1999; 23: 384-8. [CrossRef]

8. Delaitre B, Pitre J. Laparoscopic splenectomy versus open splenectomy: a comparative study. Hepatogastroenterology 1997; 44: 45-9.

9. Nobili C, Romano F, Ciravegna AL, Garancini M, Degrate L, Uggeri F, et al. Consecutive concomitant laparoscopic splenectomy and cholecystectomy: an Italian experience of 30 patients and proposition of a technique. J Laparoendosc Adv Surg Tech A 2011;21:313-7. [CrossRef]

10. Matharoo GS, Afthinos JN, Gibbs KE. Trends in splenectomy: where does laparoscopy stand? JSLS 2014; 18. [CrossRef]

11. Marte G, Scuderi V, Rocca A, Surfaro G, Migliaccio C, Ceriello A. Laparoscopic splenectomy: a single center experience. Unusual cases and expanded inclusion criteria for laparoscopic approach. Updates Surg 2013; 65: 115-9. [CrossRef]

12. Vecchio R, Intagliata E, Marchese S, La Corte F, Cacciola RR, Cacciola E. Laparoscopic splenectomy coupled with laparoscopic cholecystectomy. JSLS 2014; 18: 252-7. [CrossRef]
13. Corcione F, Pirozzi F, Aragiusto G, Galante F, Sciuto A. Laparoscopic splenectomy: experience of a single center in a series of 300 cases. Surg Endosc 2012:26: 2870-6. [CrossRef]

14. Winslow ER, Brunt LM. Perioperative outcomes of laparoscopic versus open splenectomy: a meta-analysis with an emphasis on complications. Surgery 2003; 134: 647-53; discussion 54-5. [CrossRef]

15. Andrales G, Gadacz T. The Spleen. In: Zinner M, Stanley A, editors. Maingot's Abdominal Operations. 11 ed. New York: McGraw-Hill Medical; 2007. pp. 1075-98.

16. Colovic R. [Splenectomy technic]. Acta Chirurgica Lugoslavica 2002; 49: 45-50. [CrossRef]

17. Tavakkoli A. The Spleen. In: Zinner M, Ashley JS, editors. Maingot's Abdominal Operations. New York: McGraw-Hill Medical; 2012. pp. 123949.

18. Gonzalez-Porras JR, Escalante F, Pardal E, Sierra M, Garcia-Frade LJ, Redondo $S$, et al. Safety and efficacy of splenectomy in over 65-yrs-old patients with immune thrombocytopenia. Eur J Haematol 2013; 91: 236-41. [CrossRef]

19. Zheng CX, Zheng D, Chen LH, Yu JF, Wu ZM. Laparoscopic splenectomy for immune thrombocytopenic purpura at a teaching institution. Chin Med J (Engl) 2011; 124:1175-80.

\title{
ORIJINAL ÇALIŞMA-ÖZET
}

Turk J Surg 2019; 35 (2): 111-116

\section{Dalağın iyi seyirli hastalıkları sebebiyle laparoskopik ve klasik splenektomi kullanılarak opere edilen hastaların cerrahi tedavi analizi}

\author{
Vladimir Milosavljevic ${ }^{1}$, Boris Tadic ${ }^{1}$, Nikola Grubor ${ }^{1}$, Dragan Eric ${ }^{1}$, Milorad Reljic ${ }^{1}$, Slavko Matic ${ }^{2}$ \\ ${ }^{1}$ Sırbistan Klinik Merkezi, Sindirim Cerrahisi Kliniği, Hepatobiliyer ve Pankreas Cerrahisi Bölümü, Belgrad, Sırbistan \\ ${ }^{2}$ Belgrad Üniversitesi Tıp Fakültesi, Cerrahi Anabilim Dalı, Belgrad, Sırbistan
}

\section{ÖZET}

Giriş ve Amaç: Laparoskopik splenektomi, 1990'lı yıllarda standart cerrahi ameliyat haline gelmiştir. Bu çalışmanın amacı, dalağın iyi huylu hematolojik hastalıkları için laparoskopik splenektomi olan hastaların sonuçlarını analiz etmek ve bunları açık splenektomi ile karşılaştırmaktı.

Gereç ve Yöntem: Bu çalışma, laparoskopik teknik ile opere edilen hastalar ve klasik splenektomi uygulanan hastalar olarak iki gruba ayrılan dalağın iyi seyirli hastalıkları sebebiyle Sırbistan Klinik Merkezi, Sindirim Cerrahisi Kliniğine başvuran toplam 196 hastanın verilerini analiz eden ve karşılaştıran bir retrospektif kohort çalışma olarak yürütüldü. Analiz edilen parametreler preoperatif, intraoperatif ve postoperatif olarak üç gruba ayrıldı.

Bulgular: Laparoskopik splenektomi grubunda daha az intraoperatif kan kaybı, daha düşük intraoperatif insidental komplikasyon ve daha kısa ameliyat süresi not edildi. Klasik splenektomi grubunda postoperatif komplikasyonlar ve re-operasyon insidansı daha yüksek bulundu. Postoperatif abdominal drenaj süresi, intestinal peristalside iyileşme ve postoperatif hastanede kalış süresi ile ifade edilen postoperatif iyileşme laparoskopik grupta anlamlı derecede daha kısaydı.

Sonuç: Laparoskopik splenektomi, dalağın birçok iyi seyirli hastalığının tedavisinde efektif ve güvenilir bir cerrahi işlemdir. Cerrahi takımların laparoskopik tekniklerindeki gelişme ve laparoskopik ekipmanlardaki teknik gelişim laparoskopik splenektominin standart cerrahi müdahale olarak daha geniş çapta kullanılmasına ve böylelikle dalağın daha geniş hastalık spektrumlarında hastaların daha kaliteli ve güvenilir tedavilerine sebep olabilir.

Anahtar Kelimeler: Laparoskopi, dalak, laparoskopik splenektomi, dalağın iyi seyirli hastalıkları

Doi: $10.5578 /$ turkjsurg.4324 